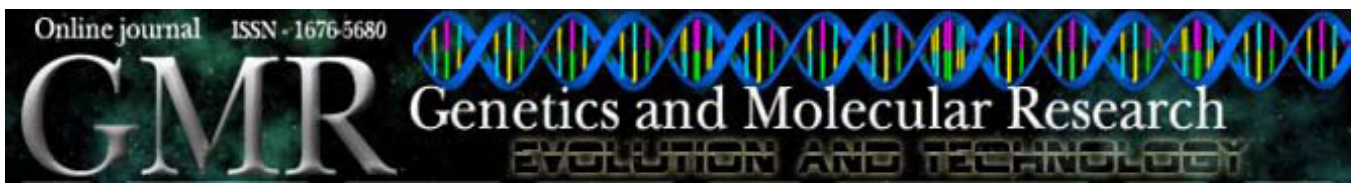

\title{
Genetic diversity in local and commercial dry bean (Phaseolus vulgaris) accessions based on microsatellite markers
}

P.D.S. Cabral ${ }^{1}$, T.C.B. Soares ${ }^{2}$, A.B.P. Lima ${ }^{2}$, F.D. de Miranda ${ }^{2}$, F.B. Souza ${ }^{2}$ and L.S.A. Gonçalves ${ }^{1}$

${ }^{1}$ Universidade Estadual do Norte Fluminense Darcy Ribeiro, Campos dos Goytacazes, RJ, Brasil

${ }^{2}$ Centro de Ciências Agrárias da Universidade Federal do Espírito Santo, Alegre, ES, Brasil

Corresponding author: P.D.S. Cabral

E-mail: pablodscabral@hotmail.com

Genet. Mol. Res. 10 (1): 140-149 (2011)

Received August 2, 2010

Accepted October 15, 2010

Published February 1, 2011

DOI 10.4238/vol10-1gmr993

ABSTRACT. Dry beans are considered to be a crop of great socio-
economic importance, because they are an inexpensive source of
nutrients and because their cultivation requires considerable manual
labor. Studies of genetic diversity have been very important for
genetic improvement programs, because they give parameters for the
identification of genitors that can provide large heterosis effects and
improved segregation in recombinants, increasing the probability of
obtaining superior genotypes in the progeny. We evaluated the genetic
diversity of 57 dry bean accessions, including 31 local accessions,
propagated by small-scale farmers, 20 accessions supplied by the
Brazilian Agricultural Research Agency, and six commercial accessions,
using 16 microsatellite primers. Among these primers, 13 were found
to be polymorphic, giving 29 polymorphic alleles. The largest number
of alleles per locus was observed for primer BM141, which had four
alleles. The polymorphic information content varied from 0.11 to 0.51 ,
observed for loci BM212 and BM141, respectively. The lowest degree 
of dissimilarity (0.0) was found between the accession Iapar 81 and the accessions E03, E04, E09, and E13 and between the accession pairs E08 with E16 and Iapar 31 with E06. The highest degree of dissimilarity was found between the accessions Carioca and E22 (1.0). Grouping analysis revealed four groups, according to the place of origin. This tendency was also found in the principal coordinate analysis. The local genotypes were found to have relatively high genetic diversity, while the EMBRAPA and commercial cultivars had a relatively narrow genetic basis.

Key words: Germplasm characterization; Fingerprint; SSR makers; Genetic resources

\section{INTRODUCTION}

The dry bean (Phaseolus vulgaris L.) is one of the most important components of the Brazilian diet, with a per capita consumption of over $17 \mathrm{~kg} /$ year $(\mathrm{CONAB}, 2006)$. It is recognized as an excellent source of protein, also containing large quantities of complex carbohydrates, fiber and isoflavonoids (Anderson et al., 1999), besides being an important source of iron, phosphorus, magnesium, and manganese, and to a lesser extent, of zinc and calcium (Broughton et al., 2003). Brazil is the world's largest producer of this legume; the States of Paraná and Minas Gerais have the largest plantings, accounting for 22.29 and $16.88 \%$, respectively, of the country's production (FAO, 2009; IBGE, 2009). In the State of Espírito Santo, dry beans are considered to be the third most important agricultural product, cultivated in an area of approximately 21.6 thousand hectares, producing 17.7 thousand metric tons, with a productivity of $832 \mathrm{~kg} / \mathrm{ha}$ in the 2008/2009 season (IBGE, 2009). It is mainly cultivated by subsistence farmers, who market excess production (Cabral et al., 2010).

Since small-scale farmers do not purchase commercial seed for planting, using seeds that they or their neighbors have produced themselves, there is a mix of varieties and natural crosses between individual plants (Bonett et al., 2006), which results in considerable genetic variability in the seed of these small producers. However, there is a tendency for loss of the genetic variability maintained by these family farms, due to the substitution of local varieties with commercial seed lines (Cardoso, 2009).

This situation underlines the importance of obtaining knowledge concerning genetic diversity of local cultivars compared to commercial and improved lines, to aid genetic improvement programs, allowing growers to make good use of existing variability and of cultivars adapted to the climatic conditions of specific regions (Loarce et al., 1996; Franco et al., 2001).

Among the tools used to estimate genetic diversity, molecular markers are especially important (Vieira et al., 2007; Gonçalves et al., 2009; Oliveira et al., 2010). Molecular markers permit us to make estimates of genetic diversity directly at the DNA level, reducing the interference of environmental variations. Also, many markers are available for each genome, there are high levels of polymorphism, and they are free of pleiotropic effects (Ferreira and Grattapaglia, 1998; Cardoso, 2009; Leal et al., 2010).

Simple-sequence repeats (SSR) or microsatellites are multiallelic and codominant and contain considerable genetic variation (Blair et al., 2003; Song et al., 2004). The high information content contained in SSR loci, together with their codominant expression, make SSRs 
ideal for gene mapping and highly efficient for linkage studies, variety protection, markerassisted selection, studies of diversity, etc. (Song et al., 2004; Leal et al., 2010).

Studies of genetic diversity have been of great importance for genetic improvement programs, because they provide information about identification parameters that have strong heterotic effects and segregate in recombinants, increasing the probability of obtaining superior genotypes in the progeny (Silva et al., 2008). Such studies also allow breeders to identify duplicates, thereby reducing the costs of maintaining germplasm banks (Oliveira, 2005).

Along this line, our objectives were to evaluate genetic diversity in 57 dry bean accessions, six of which were commercial lines and included for comparison, and to identify duplicates among the genotypes, using microsatellite molecular markers.

\section{MATERIAL AND METHODS}

\section{Plant materials}

The genetic material consisted of 57 accessions of dry beans, 20 of which were supplied by the Empresa Brasileira de Pesquisa Agropecuária (EMBRAPA) - Trigo e Sorgo, 31 by local genotypes from the Fortaleza community in the municipality of Muqui, ES, and six by commercial cultivars: Carioca, Serrano, IAPAR 31, IAPAR 44, IAPAR 81, and Pérola (Table 1).

\begin{tabular}{|c|c|c|c|c|c|c|c|c|c|}
\hline Ident. & Origin & GC & CG & W100 & Ident. & Origin & $\mathrm{GC}$ & $\mathrm{CG}$ & W100 \\
\hline Pérola & C & III & C & 23.93 & F33 & L & I & $\mathrm{R}$ & 36.38 \\
\hline $\mathrm{F} 2$ & $\mathrm{~L}$ & II & M & 21.68 & F34 & $\mathrm{L}$ & I & $\mathrm{J}$ & 46.02 \\
\hline F3 & $\mathrm{L}$ & II & M & 18.48 & F35 & $\mathrm{L}$ & II & $\mathrm{P}$ & 15.74 \\
\hline F5 & $\mathrm{L}$ & II & M & 17.13 & F36 & $\mathrm{L}$ & II & $\mathrm{O}$ & 38.99 \\
\hline F6 & $\mathrm{L}$ & II & $\mathrm{P}$ & 17.03 & F37 & $\mathrm{L}$ & II & $\mathrm{P}$ & 18.20 \\
\hline F7 & $\mathrm{L}$ & III & $\mathrm{R}$ & 19.77 & F38 & $\mathrm{L}$ & II & $\mathrm{P}$ & 15.07 \\
\hline F8 & $\mathrm{L}$ & III & $\mathrm{J}$ & 41.37 & E01 & $\mathrm{E}$ & II & $\mathrm{P}$ & 16.68 \\
\hline F9 & $\bar{L}$ & I & $\mathrm{O}$ & 36.37 & E02 & $\mathrm{E}$ & III & $\mathrm{C}$ & 22.87 \\
\hline F10 & L & III & $\mathrm{P}$ & 17.81 & E03 & E & II & $\mathrm{P}$ & 19.15 \\
\hline F11 & $\mathrm{L}$ & II & $\mathrm{P}$ & 18.50 & E04 & E & II & $\mathrm{P}$ & 19.24 \\
\hline F13 & $\mathrm{L}$ & II & M & 18.06 & Iapar 31 & $\mathrm{C}$ & II & $\mathrm{O}$ & 23.23 \\
\hline F14 & $\mathrm{L}$ & II & $\mathrm{P}$ & 17.62 & E06 & $\mathrm{E}$ & II & $\mathrm{P}$ & 22.27 \\
\hline F15 & $\mathrm{L}$ & II & $\mathrm{R}$ & 14.24 & E07 & $\mathrm{E}$ & II & $\mathrm{P}$ & 21.59 \\
\hline F16 & $\mathrm{L}$ & II & $\mathrm{C}$ & 15.77 & E08 & $\mathrm{E}$ & II & $\mathrm{P}$ & 20.13 \\
\hline F17 & $\mathrm{L}$ & II & $\mathrm{O}$ & 17.76 & E09 & $\mathrm{E}$ & II & P & 16.89 \\
\hline F18 & $\bar{L}$ & II & $\mathrm{R}$ & 14.52 & E10 & $\mathrm{E}$ & II & $\mathrm{P}$ & 26.39 \\
\hline F19 & $\mathrm{L}$ & II & M & 18.21 & E11 & E & II & $\mathrm{P}$ & 21.06 \\
\hline F20 & $\mathrm{L}$ & II & $\mathrm{O}$ & 18.16 & E12 & E & II & $\mathrm{C}$ & 22.36 \\
\hline F21 & $\mathrm{L}$ & II & M & 18.84 & E13 & E & II & $\mathrm{P}$ & 20.63 \\
\hline F23 & $\mathrm{L}$ & II & $\mathrm{P}$ & 15.28 & E14 & $\mathrm{E}$ & II & $\mathrm{P}$ & 20.21 \\
\hline F24 & $\mathrm{L}$ & II & $\mathrm{P}$ & 17.42 & E15 & $\mathrm{E}$ & II & $\mathrm{P}$ & 19.61 \\
\hline F25 & $\mathrm{L}$ & II & $\mathrm{R}$ & 17.73 & E16 & E & II & $\mathrm{P}$ & 21.39 \\
\hline F26 & $\mathrm{L}$ & II & $\mathrm{P}$ & 21.97 & E17 & E & II & $\mathrm{P}$ & 21.23 \\
\hline Iapar 81 & C & II & $\mathrm{C}$ & 20.92 & E18 & $\mathrm{E}$ & II & $\mathrm{P}$ & 20.78 \\
\hline F28 & $\mathrm{L}$ & II & M & 16.97 & E19 & $\mathrm{E}$ & III & $\mathrm{C}$ & 21.17 \\
\hline Carioca & $\mathrm{C}$ & III & $\mathrm{C}$ & 22.10 & Iapar 44 & $\mathrm{C}$ & II & $\mathrm{P}$ & 19.25 \\
\hline Serrano & $\mathrm{C}$ & II & $\mathrm{P}$ & 16.04 & E21 & $\mathrm{E}$ & II & $\mathrm{P}$ & 28.09 \\
\hline F31 & $\mathrm{L}$ & I & $\mathrm{J}$ & 36.20 & E22 & $\mathrm{E}$ & I & $\mathrm{O}$ & 36.38 \\
\hline F32 & $\mathrm{L}$ & I & $\mathrm{P}$ & 30.96 & & & & & \\
\hline
\end{tabular}

Ident. = identification of genotype origin. Origin: $\mathrm{L}=$ local; $\mathrm{E}=$ Empresa Brasileira de Pesquisa Agropecuária (EMBRAPA); $\mathrm{C}=$ commercial cultivars. $\mathrm{GC}$ : $\mathrm{I}=$ determinate bush; $\mathrm{II}=$ indeterminate bush; $\mathrm{III}=$ indeterminate prostrate. $\mathrm{CG}$ : $\mathrm{C}=$ Carioca; $\mathrm{J}=$ Jalo; $\mathrm{M}=$ Mulatinho; $\mathrm{P}=$ Black; $\mathrm{R}=$ Rosinha; $\mathrm{O}=$ others. 


\section{Molecular analysis}

The 57 accessions were planted in labeled plastic cups, containing commercial substrate and kept in a greenhouse until the first trifoliate leaves appeared. DNA was extracted from leaf samples, using the protocol of Doyle and Doyle, with some modifications, proposed by Abdelnoor et al. (1995).

The DNA was quantified by electrophoresis on $0.8 \%$ agarose gel, compared to a DNA standard (lambda DNA vector - 25, 50 and $100 \mathrm{ng}$ ). When necessary, the DNA samples were diluted to $10 \mathrm{ng} / \mu \mathrm{L}$.

Sixteen pairs of SSR primers for dry beans were selected (Gaitán-Solís et al., 2002; Oliveira, 2005; Blair et al., 2006). The selection criteria for choosing the primers were a high degree of polymorphism and a wide distribution of SSRs in the linkage groups in the consensus map for dry beans (Yu et al., 2000), to provide the largest possible coverage of the genome and linking of SSRs with agro-economically important characteristics (Table 2).

The amplification reactions of the primers were done in a final volume of $15 \mu \mathrm{L}$, containing $\mathrm{MgCl}_{2}(2.4 \mathrm{mM})$, Tris- $\mathrm{KCl}, \mathrm{pH} 8.3(0.25 \mathrm{mM})$, dNTP (0.25 mM of each nucleotide), $0.6 \mu \mathrm{M}$ of each primer, $1 \mathrm{U}$ Taq-polymerase, and $30 \mathrm{ng}$ DNA.

The amplifications were run in a thermocycler (Techne TC 412), under the following conditions: an initial step for $5 \mathrm{~min}$ at $94^{\circ} \mathrm{C}$ and 30 cycles of $1 \mathrm{~min}$ at $94^{\circ} \mathrm{C}, 1 \mathrm{~min}$ at $50^{\circ} \mathrm{C}$ and $2 \mathrm{~min}$ at $72^{\circ} \mathrm{C}$, with a final extension at $72^{\circ} \mathrm{C}$ for $10 \mathrm{~min}$. For the primers run at two annealing temperatures, only the cycles were altered: nine cycles at $94^{\circ} \mathrm{C}$ for $20 \mathrm{~s}, 58^{\circ} \mathrm{C}$ for $20 \mathrm{~s}$ and $72^{\circ} \mathrm{C}$ for $20 \mathrm{~s}$, and then 25 more cycles at $94^{\circ} \mathrm{C}$ for $20 \mathrm{~s}, 60^{\circ} \mathrm{C}$ for $20 \mathrm{~s}$ and $72^{\circ} \mathrm{C}$ for $20 \mathrm{~s}$.

The amplified fragments were separated by electrophoresis on a $3.0 \%$ agarose gel containing $0.02 \mu \mathrm{g} / \mathrm{mL}$ ethidium bromide, SB1X buffer $(0.04 \%(\mathrm{v} / \mathrm{v}) \mathrm{NaOH}$ and $0.25 \%(\mathrm{v} / \mathrm{v})$ boric acid), at $110 \mathrm{~V}$ for approximately $3 \mathrm{~h}$. After the run was terminated, the gels were photographed under ultraviolet light, using the photo-documentation system Biolocus L PIX.

\section{Data analysis}

The genetic dissimilarity values were estimated by the complement of the weighted index: $D_{i t}=1-\left(\frac{1}{2} \sum_{j=1}^{L} p_{j} c_{j}\right)$, where $L=$ total number of loci in the study; $p_{j}=\frac{a_{j}}{A}=$ weight associated with locus $j$, determined by $a_{j}$ (total number of alleles at locus $j$ ) and $A$ (total number of alleles studied), and $c_{j}=$ number of alleles in common between pairs of accessions $i$ and $i$. They were then grouped hierarchically with the unweighted paired group method using arithmetic averages (UPGMA) and principal coordinate analysis (PCoA). The polymorphic information content (PIC) was also calculated: $1-\sum_{i=1}^{a} p_{i}^{2}-\sum_{i, j=1(i \neq j)}^{a} \sum_{i}^{a} 2 p_{i}^{2} p_{j}^{2}$, where $a=$ number of loci studied and $p_{i}$ and $p_{j}=$ the allele frequencies of the loci. The calculation of the distance matrix and of PIC was done with the GENES program (Cruz, 2006), UPGMA grouping was done with the R program (www.r-project.org), and PCoA was performed with the GenALEX 6.0 program (Peakall and Smouse, 2006).

\section{RESULTS AND DISCUSSION}

Among the 16 SSR primers used to genotype the 57 accessions, 13 were polymorphic and 3 were monomorphic, with a total of 29 polymorphic alleles. The number of alleles per 
locus varied from 2 to 4 , with a mean of 2.23; primer SSR BM141 gave the largest number of alleles. Similar numbers of alleles per locus were found for beans by Campos et al. (2007), Hanai et al. (2007) and Cardoso (2009).

The PIC varied from 0.11 for locus BM212 to 0.51 for locus BM141, with a mean of 0.27 (Table 2). Similar results were obtained by Bertini et al. (2006), when they evaluated genetic diversity in cotton accessions with SSR markers. Benchimol et al. (2007) studied genetic diversity of dry beans with 87 SSR loci; they found PIC values from 0.05 to 0.83 , with a mean of 0.45 .

\begin{tabular}{|c|c|c|c|c|c|}
\hline Primer & Sequence 5'-3' & $\mathrm{Tm}$ & LG & NA & PIC \\
\hline PV-ctt001 F & GAGGGTGTTTCACTATTGTCACTGC & 48 & B04 & 2 & 0.35 \\
\hline PV-ctt001 R & TTCATGGATGGTGGAGGAACAG & & & & \\
\hline PV-gccacc $001 \mathrm{~F}$ & CGTTAGATCCCGCCCAATAGT & 48 & B02 & 2 & 0.31 \\
\hline PV-gccacc $001 \mathrm{R}$ & CCGTCCAGGAAGAGCGAGC & & & & \\
\hline $\mathrm{X} 57022 \mathrm{~F}$ & AAG GAT GGG TTC CGT GCT TG & $58 / 60$ & B04 & 2 & 0.28 \\
\hline X57022 R & CAC GGT ACA AAC CAT GCT ATC & & & & \\
\hline X74919 F & CCG TTG CCT GTA TTT CCC CAT & $58 / 60$ & B05 & 2 & 0.20 \\
\hline X74919 R & CGT GTG AAG TCA TCT GGA GTG GTC & & & & \\
\hline BM141 F & TGA GA GGA ACA ATG GTG GC & 55 & B11 & 4 & 0.51 \\
\hline BM141 R & CTC ACA AAC CAC AAC GCA CC & & & & \\
\hline BM139 F & TTA GCA ATA CCG CCA TGA GAG & $58 / 60$ & B02 & 3 & 0.21 \\
\hline BM139 R & ACT GTA GCT CAA ACA GGG CAC & & & & \\
\hline BMd10 F & GCTCACGTACGAGTTGAATCTCAG & 50 & B01 & 1 & 0.00 \\
\hline BMd10 R & ATCTGAGAGCAGCGACATGGTAG & & & & \\
\hline BM142 F & TTCCGCTGATTGGATATTAGAG & 50 & B02 & 1 & 0.00 \\
\hline BM142 R & AGCCCGTTCCTTCGTTTAG & & & & \\
\hline BM181 F & ATGCTGCGAGTTAATGATCG & 50 & B03 & 2 & 0.37 \\
\hline BM181 R & TGAGGAGCAAACAGATGAGG & & & & \\
\hline BM199 F & AAGGAGAATCAGAGAAGCCAAAAG & 50 & B04 & 1 & 0.00 \\
\hline BM199 R & TGAGGAATGGATGTAGCTCAGG & & & & \\
\hline BMd53 F & TGCTGACCAAGGAAATTCAG & 50 & B05 & 2 & 0.20 \\
\hline BMd53 R & GGAGGAGGCTTAAGCACAAA & & & & \\
\hline BM185 F & AAGGAGGTTTCTACCTAATTCC & 50 & B07 & 2 & 0.28 \\
\hline BM185 R & AAAGCAGGGATGTAGTTGC & & & & \\
\hline BM189 F & СТСССАСТCTCАСССТСАСТ & 50 & B08 & 2 & 0.33 \\
\hline BM189 R & GCGCCAAGTGAAACTAAGTAGA & & & & \\
\hline BMd54 F & GGCTCCACCATCGACTACTG & 50 & B09 & 2 & 0.12 \\
\hline BMd54 R & GAATGAGGGCGCTAAGATCA & & & & \\
\hline BM212 F & AGGAAGGGATCCAAAGTCACTC & 50 & B10 & 2 & 0.11 \\
\hline BM212 R & TGAACTTTCAGGTATTGATGAATGAAG & & & & \\
\hline PV ag001 F & СААТССТСТСТСТСТСАТТТССААТС & 50 & B11 & 2 & 0.28 \\
\hline PV ag001 R & GACCTTGAAGTCGGTGTCGTTT & & & & \\
\hline
\end{tabular}

The analysis of the dissimilarity frequencies among 1596 pair-wise combinations of the 57 common bean accessions (Figure 1) showed a non-uniform distribution, varying from 0.00 to 1.0 , with a mean of 0.45 , indicating wide genetic variability. Loarce et al. (1996) reported that breeding programs are based on the use of genetic variability within a species for the production and selection of new cultivars with high production potential.

Approximately $92 \%$ of observed total dissimilarity was concentrated within the interval 0.1-0.79. The class comprising the values from 0.2 to 0.29 gave the greatest frequency, comprising $17.89 \%$ of the total. Alzate-Marin et al. (2003) reported that 17 of 21 elite dry bean cultivars fell within the similarity distances $0.03-0.33$.

The lowest degree of dissimilarity (0.0) was found between the accessions Iapar 81 and the accessions E03, E04, E09, and E13, where they were considered to be equal, which 


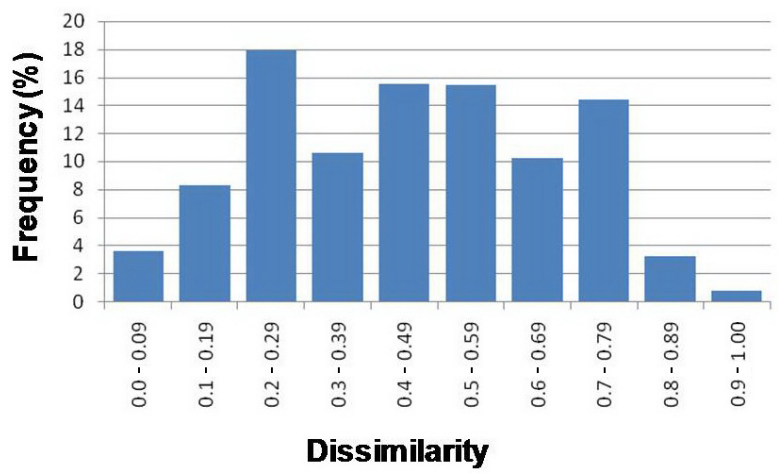

Figure 1. Frequency distribution of dissimilarity based on SSR markers for 57 dry bean genotypes in 10 classes.

also can be seen in the grouping analyses (Figure 2). The pairs E08 with E16 and Iapar 31 with E06 also showed zero dissimilarity. The highest degree of dissimilarity (1.0) was found between accessions Carioca and E22; comparisons of the latter cultivar with all the other genotypes also gave the highest mean dissimilarity (0.77), which demonstrates the high degree of divergence of this genotype with the rest of the accessions in our study.

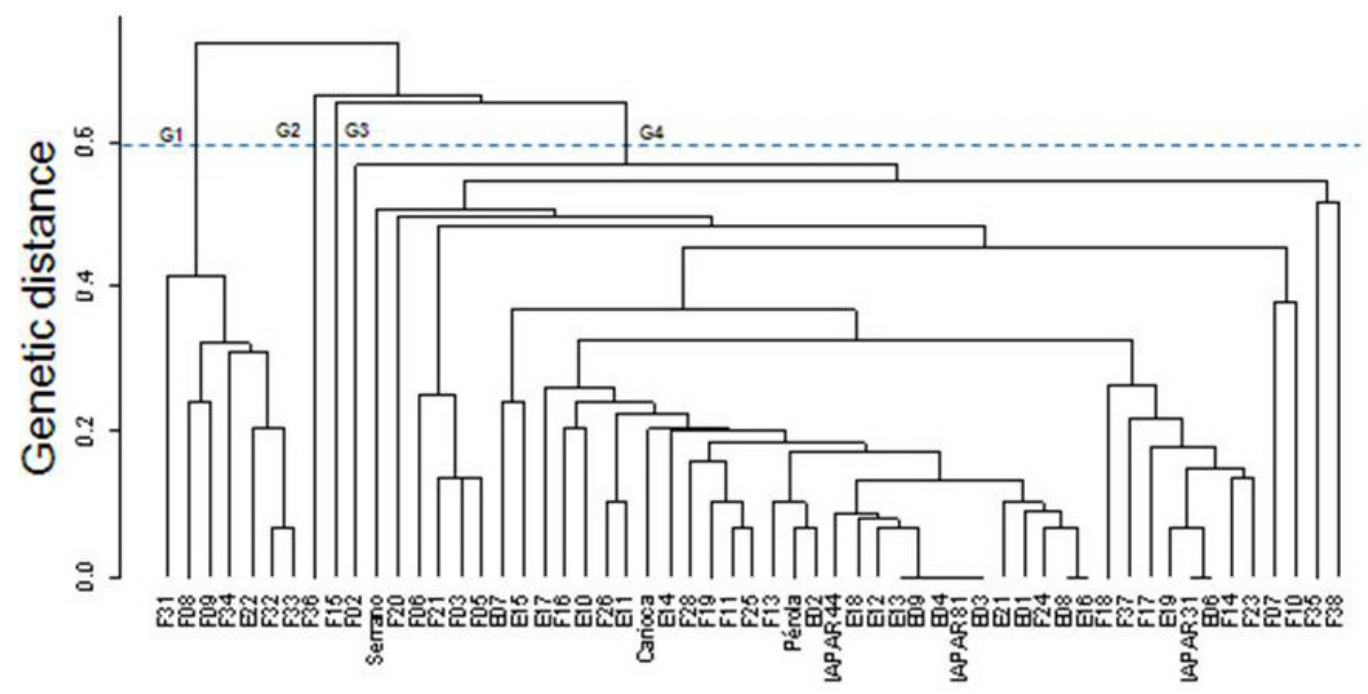

Figure 2. Dendrogram obtained using microsatellite markers with the complement of the weighted index, using the UPGMA method, of 57 dry bean genotypes. Blue line: cut-off point in the dendrogram at approximately 0.6.

The cophenetic correlation value was high and adequate $(\mathrm{r}=0.92)$. This coefficient translated the product-moment relationship, calculated between the elements of the original matrix and those of the cophenetic matrix, resulting from the simplification provided by the grouping method, after construction of the dendrogram. Values of cophenetic correlation value above 0.8 indicated good representation among the distances (Bussad et al., 1990). 
Using the cut-off point in Figure 2, four groups were formed. Group G1 included the accessions F31, F08, F09, F34, E22, F32, and F33; these accessions were considered to be of Andean origin, based on seed weight (Table 1). According to Gepts and Bliss (1986), dry bean genotypes with 100-seed weights less than 25 g normally belong to the Mesoamerican group and those with weights near or above $33 \mathrm{~g}$, would be from the Andean group.

Lioi et al. (2005), evaluating the genetic diversity of 33 dry bean populations with SSR and amplified fragment length polymorphism (AFLP) markers, observed that both types of markers grouped the genotypes into Andean and Mesoamerican centers of origin. Benchimol et al. (2007), in a study of the genetic diversity of 20 dry bean genotypes, using SSR markers, observed that two large groups were formed, one containing the Andean-origin genotypes and the other the Mesoamerican-origin genotypes. These investigators demonstrated the capacity of SSR markers to separate genotypes by centers of origin, supporting the conclusions that we made in our study.

Accession F36, alone, formed group G2. This genotype had a 100-count seed weight above $33 \mathrm{~g}$; but it did not group with the Andean-origin accessions. According to Alzate-Marin et al. (2003), some genotypes, even though they have large and heavy seeds, have a low percentage of Andean genes.

Group G3, consisting of the single accession F15, had the lowest weight per 100 seeds (14.24 g), which demonstrates genetic divergence from the other genotypes considered to be Mesoamerican (group G4).

Group G4 included all commercial cultivars (Serrano, Iapar 81, Iapar 31, Carioca, Pérola, and Iapar 44) and also nearly all cultivars from EMBRAPA, except for accession E22. This demonstrates the small degree of genetic variability among the commercial and EMBRAPA genotypes, and between these two groups. All genotypes within this group are considered to be of Mesoamerican origin, based on P100 (Table 1).

Based on the genetic dissimilarity analysis, we observed a tendency toward grouping of accessions with the same tendency for growth. Among the seven accessions of group G1, six have a determinate growth habit (type I); only accession F08 was classified as having indeterminate growth. In group G4, all accessions have indeterminate growth (types II and III). Masi et al. (2009), who studied genetic diversity of 73 dry bean genotypes, using 30 pairs of SSR primers and 393 AFLP markers, observed grouping of genotypes according to the growth patterns in both analyses.

We did not observe a tendency to group genotypes based on seed-coat color (commercial group of the grain).

The dissimilarity matrix among the commercial cultivars is given in Table 3. Dissimilarity varied from 0.07 to 0.55 , with the lowest dissimilarity observed between Iapar 81 and Iapar 44 (0.07) and the highest degree between Serrano and three other cultivars, Pérola, Carioca and Iapar $44(0.55)$. A high degree of similarity was found among the Iapar cultivars. Cultivar Serrano gave the highest dissimilarity compared to the other commercial cultivars.

Carvalho et al. (2008), using analyses made with random amplified polymorphic DNA (RAPD) markers, reported a low degree of dissimilarity among commercial dry bean cultivars. Emygdio et al. (2003), working with genetic diversity of dry bean cultivars in Rio Grande do Sul, based on RAPD markers, concluded that the commercial cultivars had a high degree of similarity with each other. 
Table 3. Dissimilarity matrix of the commercial cultivars constructed using the complement of the weighted index based on the SSR markers.

\begin{tabular}{lcccccc}
\hline & Pérola & Iapar 81 & Carioca & Serrano & Iapar 31 & Iapar 44 \\
\hline Pérola & 0 & & & & & \\
Iapar 81 & 0.14 & 0 & 0 & & & \\
Carioca & 0.21 & 0.14 & 0.55 & 0 & 0 & \\
Serrano & 0.55 & 0.48 & 0.28 & 0.34 & 0.21 & 0 \\
Iapar 31 & 0.28 & 0.14 & 0.21 & 0.55 & 0.21 & \\
Iapar 44 & 0.21 & 0.07 & & \\
\hline
\end{tabular}

The local genotypes were widely distributed in the dendrogram (Figure 2), which demonstrates wide genetic variability among those genotypes and compared to the EMBRAPA and commercial cultivars. Carvalho et al. (2008) stated that maintenance of the genetic diversity that is held by small-scale farmers can be of great value, as they probably contain alleles for local adaptations, disease resistance and tolerance to the principal edaphoclimatic adversities in the regions.

In the PCoA, the first two coordinates explained $78.03 \%$ of the total variation, with $58.21 \%$ explained by the first and $19.82 \%$ by the second (Figure 3). Somata et al. (2009), who evaluated the divergence between 39 lines of Vigna uniculata, using 48 pairs of SSR primers, observed that the first two principal components accounted for $21.74 \%$ of the variation, $14.18 \%$ by the first and $7.56 \%$ by the second. Benchimol et al. (2007) evaluated the divergence among 29 genotypes of dry beans using 87 SSR primer pairs; the three first principal components explained $45 \%$ of the total variation.

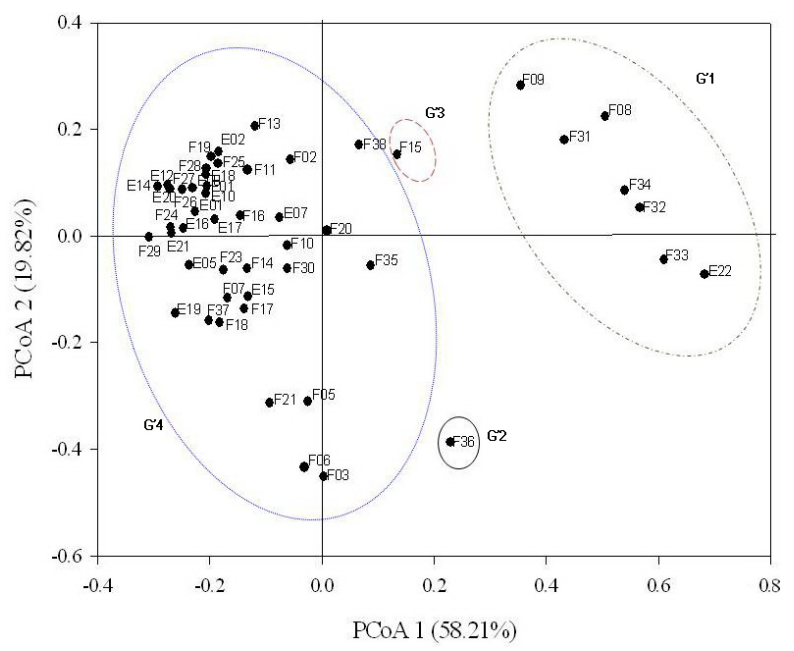

Figure 3. Principal coordinate analysis ( $\mathrm{PCoA}$ ) obtained from the complement of the weighted index based on SSR markers of 57 dry bean genotypes.

Based on the four groups formed, the genotypes classified as Andean were grouped as G'1 and G'2, and those classified as Mesoamerican origin in groups G'3 and G'4, the same groupings found with UPGMA analysis. Benchimol et al. (2007), in a study of the genetic diversity of dry beans using SSR markers, observed that the genotypes grouped according 
to center of origin, in both groupings and principal coordinate analyses, confirming what we found in our study.

\section{ACKNOWLEDGMENTS}

Research supported by Fundação de Amparo à Pesquisa do Espírito Santo (FAPES). Coordenação de Aperfeiçoamento de Pessoal de Nível Superior (CAPES) awarded a Masters of Science scholarship to P.D.S. Cabral.

\section{REFERENCES}

Abdelnoor RV, Barros EG and Moreira MA (1995). Determination of genetic diversity within Brazilian soybean germplasm using random amplified polymorphic DNA techniques and comparative analysis with pedigree. Rev. Bras. Genet. 18: 265-273.

Alzate-Marin AL, Costa MR, Sartorato A, Del Peloso MJ, et al. (2003). Genetic variability and pedigree analysis of Brazilian common bean elite genotypes. Sci. Agri. 60: 290.

Anderson JW, Smith BM and Washnock CS (1999). Cardiovascular and renal benefits of dry bean and soybean intake. Am. J. Clin. Nutr. 70: 464S-474S.

Benchimol LL, Campos T de, Carbonell SAM, Colombo C, et al. (2007). Structure of genetic diversity among common bean (Phaseolus vulgaris L.) varieties of Mesoamerican and Andean origins using new developed microsatellite markers. Genet. Res. Crop Evol. 54: 1747-1762.

Bertini CHCM, Schuster I, Sediyama T, Barros EG de, et al. (2006). Characterization and genetic diversity analysis of cotton cultivars using microsatellites. Genet. Mol. Biol. 29: 321-329.

Blair MW, Pedraza F, Buendia HF, Gaitan-Solis E, et al. (2003). Development of a genome-wide anchored microsatellite map for common bean (Phaseolus vulgaris L.). Theor. Appl. Genet. 107: 1362-1374.

Blair MW, Iriarte G and Beebe S (2006). QTL analysis of yield traits in an advanced backcross population derived from a cultivated Andean x wild common bean (Phaseolus vulgaris L.) cross. Theor. Appl. Genet. 112: 1149-1163.

Bonett LP, Gonçalves-Vidigal MC, Schuelter AR, Vidigal Filho OS, et al. (2006). Divergência genética em germoplasma de feijoeiro comum coletado no estado do Paraná, Brasil. Semina: Cien. Agrárias 27: 547-560.

Broughton WJ, Hernández G, Blair MW, Beebe S, et al. (2003). Beans (Phaseolus spp.) - model food legumes. Plant Soil 252: 55-128.

Bussad WO, Miazaki ES and Andrade D (1990). Introdução à Análise de Agrupamentos. Associação Brasileira de Estatística, São Paulo.

Cabral PDS, Soares TCB, Gonçalves LSA, Amaral Júnior AT, et al. (2010). Quantification of the diversity among common bean accessions using Ward-MLM strategy. Pesq. Agropec. Bras. 45: 1124-1132.

Campos T, Benchimol LL, Carbonell SAM, Chioratto AF, et al. (2007). Microssatélites para estudos genéticos e programas de melhoramento em feijoeiro. Pesq. Agropec. Bras. 42: 589-592.

Cardoso JMK (2009). Estimativa da Diversidade Genética entre Acessos do Tipo Carioca de Feijão Comum com Base em Marcadores Moleculares. Dissertação de Mestrado, Instituto Agronômico de Campinas, Campinas.

Carvalho MF, Farias MCFL, Coimbra JLM, Bogo A, et al. (2008). Caracterização da diversidade genética entre acessos crioulos de feijão (Phaseolus vulgaris L.) coletados em Santa Catarina por marcadores RAPD. Cienc. Rural 38: 1522-1528.

CONAB (Companhia Nacional de Abastecimento) (2006). $4^{\circ}$ Levantamento de Grãos 2006/2007. Available at [http:// www.conab.gov.br/conabweb]. Accessed January 20, 2009.

Cruz CD (2006). Programa Genes: Biometria. Editora UFV, Viçosa.

Emygdio BM, Antunes IF, Nedel JL and Choer E (2003). Diversidade genética em cultivares locais e comerciais de feijão baseada em marcadores RAPD. Pesq. Agropec. Bras. 38: 1165-1171.

FAO (Food Agricultural Organization) (2009). Agriculture Data. Available at [http://faostat.fao.org/site/339/default.aspx 2009]. Accessed November 22, 2009.

Ferreira ME and Grattapaglia D (1998). Introdução ao Uso de Marcadores Moleculares em Análise Genética. 3rd edn. EMBRAPA-CENARGEN, Brasília.

Franco MC, Cassini STA, Oliveira VR and Tsai SM (2001). Caracterização da diversidade genética em feijão por meio de marcador RAPD. Pesq. Agropec. Bras. 36: 381-385.

Gaitán-Solís E, Duque MC, Edwards KJ and Tohme J (2002). Microsatellite repeats in common bean (Phaseolus vulgaris): 
isolation, characterization, and cross-species amplification in Phaseolus ssp. Crop Sci. 42: 2128-2136.

Gepts P and Bliss FA (1986). Phaseolin variability among wild and cultivated common beans (Phaseolus vulgaris) from Colombia. Econ. Bot. 40: 469-478.

Gonçalves LS, Rodrigues R, do Amaral Junior AT, Karasawa M, et al. (2009). Heirloom tomato gene bank: assessing genetic divergence based on morphological, agronomic and molecular data using a Ward-modified location model. Genet. Mol. Res. 8: 364-374.

Hanai LR, de Campos T, Camargo LE, Benchimol LL, et al. (2007). Development, characterization, and comparative analysis of polymorphism at common bean SSR loci isolated from genic and genomic sources. Genome 50: 266-277.

IBGE (Instituto Brasileiro de Geografia e Estatistica) (2009). Área Plantada, Área Colhida, Quantidade, Rendimento Médio e Valor da Produção dos Principais Produtos das Lavouras Temporárias. Available at [http: //www.ibge.gov. br]. Accessed November 25, 2009.

Leal AA, Mangolin CA, do Amaral ATJ, Goncalves LS, et al. (2010). Efficiency of RAPD versus SSR markers for determining genetic diversity among popcorn lines. Genet. Mol. Res. 9: 9-18.

Lioi L, Piergiovanni AR, Pignone D, Puglisi S, et al. (2005). Genetic diversity of some surviving on-farm Italian common bean (Phaseolus vulgaris L.) landraces. Plant Breed. 124: 576-581.

Loarce Y, Gallego R and Ferrer EA (1996). Comparative analysis of the genetic relationship between rye cultivars using RFLP and RAPD markers. Euphytica 88: 107-115.

Masi P, Logozzo G, Donini P and Zeuli PS (2009). Analysis of genetic structure in widely distributed common bean landraces with different plant growth habits using SSR and AFLP markers. Crop Sci. 49: 187-199.

Oliveira MSP (2005). Caracterização Molecular e Morfoagronômica de Germoplasma de Açaizeiro. Tese de doutorado. UFLA, Lavras.

Oliveira EC, Amaral Junior AT, Goncalves LS, Pena GF, et al. (2010). Optimizing the efficiency of the touchdown technique for detecting inter-simple sequence repeat markers in corn (Zea mays). Genet. Mol. Res. 9: 835-842.

Peakall R and Smouse PE (2006). Genalex 6: genetic analysis in Excel. Population genetic software for teaching and research. Mol. Ecol. Notes 6: 288-295.

Silva GO, Pereira AS, Souza VQ, Carvalho FIF, et al. (2008). Importância de caracteres na dissimilaridade de progênies de batata em gerações iniciais de seleção. Bragantia 67: 141-144.

Somata P, Sommanas W and Srinives P (2009). Molecular diversity assessment of AVRDC - the world vegetable center elite-parental mungbeans. Breed. Sci. 59: 149-157.

Song QJ, Marek LF, Shoemaker RC, Lark KG, et al. (2004). A new integrated genetic linkage map of the soybean. Theor. Appl. Genet. 109: 122-128.

Vieira EA, Carvalho FIF, Bertan I, Kopp MM, et al. (2007). Association between genetic distances in wheat (Triticum aestivum) as estimated by AFLP and morphological markers. Genet. Mol. Biol. 30: 392-399.

Yu K, Park SJ, Poysa V and Gepts P (2000). Integration of simple sequence repeat (SSR) markers into a molecular linkage map of common bean (Phaseolus vulgaris L.). J. Hered. 91: 429-434. 